\title{
The effects of cognitive and non-cognitive skills on early school-leaving
}

Citation for published version (APA):

Traag, T., \& van der Velden, R. K. W. (2012). The effects of cognitive and non-cognitive skills on early school-leaving. METEOR, Maastricht University School of Business and Economics. METEOR Research Memorandum No. 020 https://doi.org/10.26481/umamet.2012020

Document status and date:

Published: 01/01/2012

DOI:

10.26481/umamet.2012020

Document Version:

Publisher's PDF, also known as Version of record

\section{Please check the document version of this publication:}

- A submitted manuscript is the version of the article upon submission and before peer-review. There can be important differences between the submitted version and the official published version of record.

People interested in the research are advised to contact the author for the final version of the publication, or visit the DOI to the publisher's website.

- The final author version and the galley proof are versions of the publication after peer review.

- The final published version features the final layout of the paper including the volume, issue and page numbers.

Link to publication

\footnotetext{
General rights rights.

- You may freely distribute the URL identifying the publication in the public portal. please follow below link for the End User Agreement:

www.umlib.nl/taverne-license

Take down policy

If you believe that this document breaches copyright please contact us at:

repository@maastrichtuniversity.nl

providing details and we will investigate your claim.
}

Copyright and moral rights for the publications made accessible in the public portal are retained by the authors and/or other copyright owners and it is a condition of accessing publications that users recognise and abide by the legal requirements associated with these

- Users may download and print one copy of any publication from the public portal for the purpose of private study or research.

- You may not further distribute the material or use it for any profit-making activity or commercial gain

If the publication is distributed under the terms of Article $25 \mathrm{fa}$ of the Dutch Copyright Act, indicated by the "Taverne" license above, 


\section{Maastricht University}

Tanja Traag, Rolf van der Velden

The Effects of Cognitive and NonCognitive Skills on Early SchoolLeaving

$\mathrm{RM} / 12 / 020$

\section{METEOR}

Maastricht University School of Business and Economics

Maastricht Research school of Economics

of Technology and Organization

PO. Box 616

NL-6200 MD Maastricht

The Netherlands 


\title{
THE EFFECTS OF COGNITIVE AND NON-COGNITIVE SKILLS ON EARLY SCHOOL-LEAVING
}

\author{
Tanja Traag and Rolf van der Velden
}

\begin{abstract}
In this paper we investigate how non-cognitive skills can explain individual differences in early schoolleaving controlling for cognitive skills. We use a large Dutch representative longitudinal cohort study “Secondary Education Pupil Cohort 1999." In the first year of this study, personality was assessed with the FFPI as part of a comprehensive student questionnaire. Our results show that while cognitive skills play an important role in explaining early school-leaving, non-cognitive skills such as achievement motivation, conscientiousness, agreeableness and openness to experience play an important role as well. In addition, we find that differences in non-cognitive skills affect the impact of cognitive skills performance on early school-leaving.
\end{abstract}

Keywords: cognitive skills, achievement motivation, big five, early school-leaving) JEL codes (I20, I21 en I24)

\section{Introduction}

Over the past decades, a large number of studies have shown differences in Cognitive Skills to be important predictors for educational failure, i.e. early school-leaving. Early school-leavers show lower levels of Cognitive Skills and perform less well in school compared to other students (Alexander, Entwisle, \& Kabbani, 2001; Audas \& Willms, 2001; Cairns, Cairns, \& Neckerman, 1989; ChamorroPremuzic \& Furnham, 2006; Ensminger \& Slusarcick, 1992; Furnham, 2008; Heckman \& Rubinstein, 2001; Traag \& Van der Velden, 2011). Although differences in Cognitive Skills are one of the strongest predictors of school failure, other factors play a role as well. One of these factors are the Non-Cognitive Skills. This was already recognised by one of the pioneers in intelligence testing, Alfred Binet, who stated that: 'A child, even if intelligent, will learn little in class if he never listens, if he spends his time in playing tricks, in giggling, in playing truant' (Binet, Simon, \& Kite, 1916 p.254 ). Eysenck (1947) introduced the first paradigm for consistently studying the impact of Personality Traits on academic performance

\footnotetext{
1 We would like to thank Angela Lee Duckworth, Jannes de Vries, Martin Humburg, and Christoph Meng for their helpful comments.
} 
(Petrides, Chamorro-Premuzic, Frederickson, \& Furnham, 2005). Later, other models for the measurement of Personality Traits, such as the Five Factor Personality Inventory FFPI (McCrae \& Paul T. Costa, 1997) emerged.

In recent years more and more attention has been given to the importance of Non-Cognitive Skills in explaining individual differences in educational success as well as labour market outcomes. Heckman, Stixrud and Urzua (2006) showed that both Cognitive and Non-Cognitive Skills determine social and economic success. However, they also found evidence that Non-Cognitive Skills may be as important as or even more important than Cognitive Skills in explaining labour market outcomes such as wage levels, employment chances or occupational choice. In that same study, Heckman et al. also evaluated the impact of both risk behaviour and schooling decisions. They showed that while Cognitive Skills were the most important factor in the decision to drop out of school, Non-Cognitive Skills were especially important in explaining who attained the General Education Diploma (GED) ${ }^{2}$ after dropping out of school and who did not. This confirmed the hypothesis of an earlier study by Heckman and Rubinstein, which showed that while GED receivers had equally high scores on achievement tests as those who attained a high school diploma, they had lower levels of Non-Cognitive Skills (Heckman \& Rubinstein, 2001).

In most studies investigating the impact of Cognitive and Non-Cognitive Skills on educational achievement, both categories of skills are treated as additive factors in explaining educational and labour market outcomes. In other words, many of these studies aim to show that Non-Cognitive Skills play a role after controlling for Cognitive Skills. But there is a complex interplay between the two factors as well, that is often overlooked. In 1964, Vroom developed the Expectancy theory in his study on the motivations for decision-making. According to Vroom (1964), performance is a multiplicative function of both ability and motivation:

\section{Perfomance $=f($ ability $\times$ motivation $)$}

From this formula it follows that, while ability affects performance, the impact of ability is dependent on a person's motivation level and vice versa. For those with low motivation, increases in ability will result in smaller increases in performance than for those who are highly motivated. And conversely, for those with low ability, an increase in the motivation levels will have less impact on the performance level than for the ones with high ability (Vroom, 1964: p. 203).

The aim of this paper is to gain a better understanding of the process of early school-leaving by studying the interplay between Cognitive and Non-Cognitive Skills. We will use a unique dataset that enables us to overcome the shortcomings of many studies which struggle with contemporaneous measures

\footnotetext{
2 The GED can be attained after taking a test in five subject areas. Only individuals who do not have a high school diploma can take the GED test.
} 
of educational outcomes and measures of Cognitive and Non-Cognitive Skills. By measuring both skill types at the age of twelve and observing subsequent early school-leaving, we are able to ensure a credible claim for causality. Also, we will contribute to the existing literature by explicitly looking at the interaction effects between Cognitive and Non-Cognitive Skills. We shall apply Vroom's formula to predict individual differences in early school-leaving risks, but also extend his formula by broadening motivation to include a wider array of Non-Cognitive Skills, using both measures of Achievement Motivation in school as well as Personality Traits based on the FFPI (McCrae \& Paul T. Costa, 1997). This approach will help us to get an insight into how and why some adolescents are unable to obtain a full upper secondary qualification and thus become early school-leavers.

The results show that while Cognitive Skills are the most important predictor of early schoolleaving, Non-Cognitive Skills also have a notable impact on the risk of becoming an early school-leaver. We find that Conscientiousness and Agreeableness protect against early school-leaving, while Openness to Experience increases this risk. In addition, we find that the protective effect of Conscientiousness holds specifically for students with low levels of Cognitive Skills, while the protective effect of Agreeableness holds specifically for students with medium-level Cognitive Skills.. Openness to Experience, on the other hand, decreases the protective effect of Cognitive Skills, especially for students with high levels of Cognitive Skills.

The paper is structured as follows: section 2 presents a literature review on Non-Cognitive Skills as predictors of school success. Next, in Section 3 we describe the data used for this study and our modelling strategy. In section 4 , we report our results. Lastly, section 5 contains concluding remarks.

\section{Non-Cognitive Skills as predictors of school success}

\subsection{Personality Traits}

Although Cognitive Skills have been shown to be an important factor in explaining individual differences in school success, as well as in health and work outcomes (Furnham, 2008), differences in Cognitive Skills alone are insufficient to fully explain why an individual succeeds or fails in school (ChamorroPremuzic \& Furnham, 2006; Heckman \& Rubinstein, 2001). This has led to a new body of research on non-cognitive predictors for school success, especially the Big Five Personality dimensions. O'Connor and Paunonen (2007) offer two broad justifications for using Personality Traits to predict school success. First, Personality affects a person's habits, which in turn can influence school success (Rothstein, Paunonen, Rush, \& King, 1994). Second, while Cognitive Skills reflect what a person is able to accomplish, the Personality Traits reflect what they will do and how they will use these abilities (Chamorro-Premuzic \& Furnham, 2003). 
The Five-Factor Model of Personality (McCrae \& Paul T. Costa, 1997) differentiates Personality factors that reside at the highest level of the Personality hierarchy, encompassing the entire domain of lower level Personality Traits: Openness to Experience, Conscientiousness, Extraversion, Agreeableness and Emotional Stability. There has been extensive research on the direct relationship between Personality Traits and school success (see Chamorro-Premuzic \& Furnham, 2005 for a literature review).

Openness to Experience is characterized by 'intellectence' (acquired Cognitive Skills) and unconventionality (imaginative, autonomous and nonconforming) (Judge, Higgins, Thoresen, \& Barrick, 1999). The study by Ackerman and Heggestad (1997) showed Openness to Experience to have a positive relationship with school success, even when controlling for intelligence. However, more recent studies have not been able to replicate these results. One explanation could be that the creative and imaginative nature of these students is disadvantageous in academic settings, especially when reproduction of curricular content is the main requirement (Fruyt \& Mervielde, 1996).

Conscientiousness manifests itself in a number of facets, like the will to achieve, dependability and orderliness, and has consistently been found to predict academic achievement throughout the life course (Fruyt \& Mervielde, 1996; Poropat, 2009). Some authors have speculated that Conscientiousness may affect academic performance beyond ability, and even compensate for poor intellectual ability (Chamorro-Premuzic \& Furnham, 2003).

Extraversion is a rather broad construct that consists of sociability as well as social orientation, dominance and assertiveness. Research among young children has shown a positive relationship between Extraversion and school success, while evidence among adolescents and adults has shown a negative effect (Chamorro-Premuzic \& Furnham, 2003). These conflicting results have been attributed to the difference between the sociable environment of primary schools as opposed to the more formal atmosphere of secondary and higher education (Matthews, Zeidner, \& Roberts, 2006). With respect to a possible interaction effect, the study by Petrides et al. (2005) showed differential effects of Extraversion between low and high ability boys: for low ability boys, Extraversion had a detrimental effect on school success, while for high ability boys Extraversion had no effect. One possible explanation is that those with low ability will need to invest a lot of time and effort in their educational career in order to succeed. However, extraverts tend to be pleasure-seeking and outgoing, making them less likely to spend time on their education in favour of extra-curricular activities.

Agreeable people are trustable and caring as well as likable. No direct significant effects of agreeableness on educational success have been found, although some antisocial Personality Traits associated with low Agreeableness may have detrimental effects (Matthews et al., 2006).

Emotional Stability generally refers to a lack of positive psychological adjustment. Evidence on how and why neuroticism affects school success is inconclusive. A study by McKenzie and Tindell (1993) 
showed neuroticism to be correlated with low achievement only for students with a weak superego, indicating that self-control and focusing of motivation compensate for negative emotionality (Matthews et al., 2006).

\subsection{Achievement Motivation}

Motivational differences are assumed to be partly reflected by differences in Personality Traits, specifically Conscientiousness. However, whereas Personality Traits describe a person's characteristics in all kinds of situations, constructs from the tradition of Achievement Motivation research are specifically designed to describe differences between individuals in a learning and achievement-related setting (Steinmayr \& Spinath, 2008). Traditionally, Achievement Motivation was thought to simply reflect the balance between striving for success on the one hand and the fear of failure on the other, while later research showed that motivation could be understood as (a) the choice to make an effort, (b) an assessment of the level of effort to be invested, and (c) the choice to persist at this level (Matthews et al., 2006). Cognitive Skills and Achievement Motivation are not isolated concepts. In fact it seems reasonable to assume that Cognitive Skills, Achievement Motivation and Personality Traits develop along mutually causal lines, where successful performance in certain tasks increases interest and thus increases Achievement Motivation (Ackerman \& Heggestad, 1997: p. 239). In their study of the economics and psychology of Personality Traits, Borghans, Duckworth, Heckman and Ter Weel (2008) stress that discerning between measures of Cognitive Skills, Achievement Motivation and Personality is complicated since the measurement of these concepts is affected by factors such as the respondent's motivation to perform well, test anxiety and differences in Personality, i.e. openness, curiosity and perseverance. For one, this means that there is overlap between Achievement Motivation and Conscientiousness. However, the complex interplay between these Traits is not the focus of this study. Therefore we estimate the effect of Achievement Motivation and Personality Traits on school success in two separate models.

\subsection{Hypotheses}

In this paper, we explore how Achievement Motivation and Personality affect early school-leaving when controlling for Cognitive Skills. Based on our literature review we assume the following hypotheses:

1. Achievement Motivation significantly decreases the risk of early school-leaving.

2. Personality Traits can significantly predict the risk of leaving school early. Based on previous findings in the literature we expect to find significant negative effects for Conscientiousness and Openness to Experience and a positive effect for Extraversion. Based on previous studies, we do not expect to find any significant effects for Agreeableness and Emotional Stability. 
As was assumed by Vroom (1964), the relationship between performance, ability and motivation is a multiplicative function, assuming that the impact of ability is dependent on a person's motivation level and vice versa. This implies interaction effects between Cognitive and Non-Cognitive Skills on early school-leaving. Based on this assumption of a multiplicative relationship between performance, ability and motivation, we assume that the impact of Achievement Motivation is stronger for high ability students than for low ability students:

3. There is a significant negative interaction effect between Cognitive and Non-Cognitive Skills on the risk of early school-leaving.

Based on previous findings, we expect to find negative effects for Conscientiousness and Openness to Experience and a positive effect of Extraversion. In concordance with Vroom's assumption of a multiplicative relationship between Cognitive and Non-Cognitive Skills we therefore expect that:

4. There is a significant negative interaction effect of Conscientiousness and Openness to Experience with Cognitive Skills on early school-leaving, and a positive interaction effect for Extraversion with Cognitive Skills. Again we do not expect to find any significant interaction effects for Agreeableness and Emotional Stability.

\section{Research design}

For this study we use a large representative longitudinal survey of Dutch youth carried out by Statistics Netherlands (CBS). This survey, the Secondary Education Pupil Cohort 1999 (VOCL'99), consists of 19,391 students from a random sample of 126 schools who were in the first grade of secondary education (age 12) in 1999/2000 (Van Berkel, 1999). The cohort is shown to be representative for 12 year-old students in the Netherlands (Kuyper \& Van der Werf, 2003). The educational careers of these students were followed up annually by matching the cohort to the national educational register until the year 2010/ 11. The register data provide information on the school type, grade and examination results. We can therefore determine the educational level attained at any time. Furthermore, an achievement test was administered during the first year of the study, providing us with a good measure of the Cognitive Skills at the start of secondary school. In addition, tests were conducted on Achievement Motivation and Personality. A written questionnaire was also given to the parents of the surveyed students with the aim of collecting information about the family background of the pupils like socioeconomic background and parenting styles (Kuyper, Lubbers, \& Van der Werf, 2003). 
From our initial sample of 19,391 students, we removed those who had died, were seriously ill $^{3}$ or had moved abroad within the 1999/ 00-2010/ 11 period (473 students). Moreover, we excluded students who had missing values on our key variables: Cognitive Skills, Achievement Motivation or Personality Traits (4,688). This left 14,230 students for our analyses. In this sample, 53.4 percent started education in the pre-vocational track, 49.4 percent was male and the average score on the test measuring Cognitive Skills was .59. In the original sample, 56.5 percent started in pre-vocational education, 50 percent was male and the average score on the Cognitive Skills test was .57. So in general we can say that the selected sample is biased somewhat towards a sample of more highly skilled students, slightly more often being female. The risk of becoming an early school-leaver is highest for those who started their education career in the pre-vocational track. About one third of these students do not attain a full upper secondary qualification. For those who started in the general tracks preparing for vocational colleges or universities, the risk is much lower (see table 1). Only 8 percent of the students who started in the pre-college track did not attain a full upper secondary qualification. For students who started in the pre-university track, only 5 percent left school early. Since we observe less low educated students in our sample, and consequently those with higher Cognitive Skills, we expect our estimates to be somewhat underestimated.

\section{$<$ Table 1 about here>}

\subsection{Measuring early school-leaving}

The Dutch education system is highly stratified (see appendix 1). After six years of primary education, students enter secondary education at the age of 12 . Here they have to choose between three tracks: one preparing for university education (VWO, duration 6 years), one preparing for a college for higher vocational education (HAVO, duration 5 years) and one track preparing for vocational education at the upper secondary level (VMBO, duration 4 years). Track placement takes place on the basis of a nationwide test, called CITO-test, at the end of primary education and the advice of the primary school teacher. Subsequently, depending on the track chosen, students can either leave education or enter one of three upper secondary vocational tracks, higher vocational education, or university. In the Dutch education system, compulsory education starts at age five (although most children start at age 4) and lasts until the

\footnotetext{
${ }^{3}$ A total of 31 students were removed from the sample due to serious illness in the beginning of their educational career, that prevented them from attending education for long periods of time. In the Netherlands, health problems are viewed as an important predictor for early school-leaving (Researchcentrum voor Onderwijs en Arbeidsmarkt, 2011), but this refers mainly to mental health problems like behavioral disturbances. These students are still included in the sample. A previous study on the impact of physical health problems on early school-leaving showed only very limited effects, and only for students in pre-university education (Van Heesch, Bosma, Traag, \& Otten, 2011). Therefore we do not expect to find any bias in our results based on this selection.
} 
age of 16. Since 2007, Dutch youths are obliged to learn or to work until the age of 18 or until completion of a full upper secondary (ISCED 3) qualification ('kwalificatieplicht'). Those who have not attained this minimum education level at age 18 are required to either resume education or work until the age of 27 ('leerwerkplicht', officially adopted in 2009).

In this paper, an early school-leaver is defined as a student who was no longer enrolled in education in September 2010 (2010/ 11 school year) and who did not have a full upper secondary qualification (see appendix 1). This definition is in line with the international definition of early schoolleaving used by the OECD and Eurostat. In our sub-sample, 2,060 (18.9 percent) students had not attained this minimum level of education.

\subsection{Independent variables}

Cognitive Skills were measured using a test developed by the Cito-group (the Dutch equivalent of Educational Testing Services) which was administered in January 2000, four months after entry into secondary education. This test is a sub-test of the test used at the end of primary education to determine track placement. The test consisted of three subtests for text comprehension, arithmetic and information processing (see (Lubbers, 2004), for a detailed description of the testing procedure). Each test has 20 multiple-choice items. For comparability purposes, this and all other scale variables used were rescaled so that the lowest score was 0 and the highest score was 1.

Achievement Motivation was also measured in January 2000 using the Academic Achievement Motivation Test (Hermans, 1970) and assesses a student's motivation to perform well in school. The scale consists of 9 items indicating the responses to questions like: “I do my homework much better when I'm worried about failing" and "I always try to do my homework as well as possible". Previous studies have shown Achievement Motivation to be a key predictor of school success (Hustinx, Kuyper, M.P.C. Van der Werf, \& Dijkstra, 2009; Kuyper, Dijkstra, Buunk, \& Werf, 2011; Kuyper, Werf, \& Lubbers, 2000).

Personality was assessed one year later (February 2001), when the students were in grade 2 of secondary education, with the Five Factor Personality Inventory (FFPI) developed by Hendriks, Kuyper, Offringa \& Van Der Werf (2008). The instrument has been tested nationally and internationally and has proven to be a reliable and valid measure to assess the Big Five Personality Traits (Hendriks et al., 2008; Hendriks, Perugini, Angleitner, Ostendorf, Johnson, Fruyt, Hřebíčková, Kreitler, Murakami, Bratko, Conner, Nagy, Rodgríguez-Fornells, \& Ruisel, 2003). The FFPI yields a person's scores on Openness to Experience, Conscientiousness, Extraversion, Agreeableness and Emotional Stability. Responses were given on a five-point scale ranging from $1=$ not at all applicable to $5=$ entirely applicable. A person's 'compatible anchored factor scores' were computed using the FFPI scoring software. Compatible anchored factor scores are standardized scores anchored at the scale midpoint. They are computed as 
weighted linear combinations of a person's 100 item responses, using item weights established in the Dutch norm sample (Hendriks et al., 2008). As indicated above, the scores were rescaled so that the lowest score was 0 and the highest score was 1 .

The VOCL'99 data comprise a number of socioeconomic background variables that have been shown in earlier research to affect school success: gender, migrant status, parental educational level ${ }^{4}$, and parental income ${ }^{5}$ (Bhrolcháin, Chappell, Diamond, \& Jameson, 2000; De Graaf, 1986; Heard, 2004; Lamb, 1994; McLanahan \& Sandefur, 1994; Nord \& West, 2001; Rumberger, 1983, 1987; Traag \& Van der Velden, 2011). Some of these characteristics are missing for certain students in the survey if parents did not answer all questions. For these individuals we replaced the missing value by the population average and included characteristic missing dummies to capture potential selection in responding to the survey. In addition, we shall control for the education level of the class in 1st grade, using two dummies for pre-college track and pre-university track with the pre-vocational track as the reference category.

\section{Results}

\subsection{Descriptive results}

Table 2 presents the differences in Cognitive and Non-Cognitive Skills of early school-leavers versus those who attained the minimum education level (regular school-leavers). The first important finding from this table is that there is a clear positive relationship between Cognitive Skills and early school-leaving, as could be expected. The differences between the two groups are also depicted figure 1. While early schoolleavers on average perform less well in school compared to those who attained the minimum education level $\left(\mathrm{t}=47.137^{* *}\right)$, the graph also shows that there is some overlap in Cognitive Skills between the two groups, indicating that a significant proportion of our early school-leavers have sufficient skills, but do not manage to attain a certain level of education. In Dutch literature, this distinction between those who

\footnotetext{
${ }^{4}$ Parental education was collected in the parental questionnaire during school year 1999/ 00. For both parents (if available) the highest education level was recoded into the number of years of schooling needed to obtain this level (Bosker, Van Der Velden, $\&$ Hofman, 1985) varying from 6 (primary education) to 19 years (university education) of schooling. To reflect the parental educational level the mean of the father and the mother was taken.

5 Parental income is measured as the log of the mean personal income of both the father and the mother (if available) in 2004 and was taken from the Annual Income Registry kept by Statistics Netherlands and based on information from the Dutch Tax Administration. It includes income from labour as well as social security benefits and other sources of income. For single parent households, only the income of the resident parent was used. Parents with zero or negative income (124 cases from the initial population) were recoded to having zero income. In cases where the income could not be matched (702 cases from the initial population), the income was replaced by the population mean.
} 
cannot and those we will not attain a full upper secondary qualification is often referred to as the 'classical at-risk student' and the 'resigner'(Allen \& Meng, 2010): the classical at-risk student is the student that lacks sufficient Cognitive Skills to attain a certain level, while the resigner is the student that is able to attain a certain level of education based on cognitive ability, yet makes the decision to resign from education nevertheless. This is exactly the group where Non-Cognitive Skills may be expected to guide the decision to invest in further schooling or not.

$<$ Table 2 about here $>$

$<$ Figure 1 about here>

Although in most cases we also find significant differences between early and regular school-leavers in the area of Non-Cognitive Skills, these differences are quite small compared to the differences in Cognitive Skills. For Achievement Motivation, Extraversion, Agreeableness and Emotional Stability, we find that the regular school-leavers have on average somewhat higher scores than the early school-leavers, but for Conscientiousness and Openness to Experience, the two distributions almost completely overlap (see figure 2). This is not fully in line with our expectations, as we expected to find higher levels of Conscientiousness and Openness to Experience among regular school-leavers and lower levels of Extraversion among early school-leavers.

$<$ Figure 2 about here>

\subsection{Logistic regression analyses}

To explore how Cognitive and Non-Cognitive Skills affect the risk of early school-leaving directly and indirectly we now turn to a logistic model. We shall estimate a series of logistic regression models that estimate the propensity that an individual $i$ is an early school-leaver (ESL). In our first model (equation 1), we estimate the effect of our Cognitive Skills measure:

$$
\text { ESL }_{i}=\beta_{0}+\beta_{1} \text { CognitiveSkills }_{i}+u_{i}
$$

Where $E S L_{i}$ indicates whether individual $i$ is an early school-leaver, Cognitiveskills is a vector of Cognitive Skills, and $u_{i}$ the idiosyncratic error term. In the second model, we add our measure of Achievement Motivation:

$$
\text { ESL }_{i}=\beta_{0}+\beta_{1} \text { CognitiveSkills }_{i}+\beta_{2} \text { AchievementMotivation }_{i}+u_{i}
$$


In the third model, we add a vector Socio-EconomicBackground ${ }_{i}$ to the equation with controls for the education level of the class in the 1 st grade of secondary education, gender, migrant status, parental education, parental income and parental communication as well as dummies for missing values.

$$
\begin{aligned}
& \text { ESL }_{i}=\beta_{0}+\beta_{1} \text { CognitiveSkills }_{i}+\beta_{2} \text { AchievementMotivation }_{i}+ \\
& \beta_{3} \text { Socio }_{- \text {EconomicBackground }_{i}+u_{i}}
\end{aligned}
$$

Lastly, we add the interaction term between Cognitive Skills and Achievement Motivation to the model. ESL $_{i}=\beta_{0}+\beta_{1}$ CognitiveSkills $_{i}+\beta_{2}$ AchievementMotivation $_{i}+$

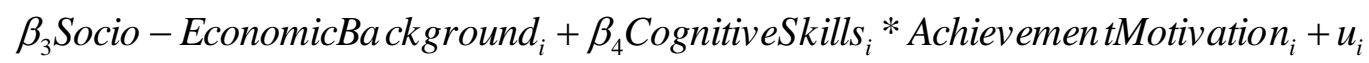

As indicated earlier, we shall run separate analyses for the Personality Traits as these are partly correlated with Achievement Motivation. We start with a model in which we have a vector for CognitiveSkills $s_{i}$ and a vector BigFive ${ }_{i}$ representing the different Personality Traits (Openness to Experience, Conscientiousness, Extraversion, Agreeableness, and Emotional Stability):

ESL $_{i}=\beta_{0}+\beta_{1}$ CognitiveSkills $_{i}+\beta_{2}$ BigFive $_{i}+u_{i}$

Again, we add some control variables to control for differences in socio-economic background and other controls as well as dummies for missing values:

ESL $_{i}=\beta_{0}+\beta_{1}$ CognitiveSkills $_{i}+\beta_{2}$ BigFive $_{i}+\beta_{3}$ Socio $_{-} E$ conomicBackground $_{i}+u_{i}$

In the final model, we add interaction terms between Cognitive Skills and Personality Traits ${ }^{6}$ :

$$
\begin{aligned}
& \text { ESL }_{i}=\beta_{0}+\beta_{1} \text { CognitiveSkill }_{i}+\beta_{2} \text { BigFive }_{i}+\beta_{3}{\text { Socio }- \text { EconomicBackground }_{i}+} \\
& \beta_{4} \text { CognitiveSkills }_{i} * \text { BigFive }_{i}+u_{i}
\end{aligned}
$$

\subsection{The effect of Achievement Motivation on early school-leaving}

Table 3 presents the results for the first set of analyses. In Model 1, we estimate the risk of becoming an early school-leaver based on one's Cognitive Skills. As the results show, there is a significant negative effect of Cognitive Skills, indicating that the higher a student scored on the performance test in the first grade of secondary education, the lower the risk to become an early school-leaver. For students with a

\footnotetext{
${ }^{6}$ Borghans et al. (2008) suggest that in some cases the relationship between non-cognitive skills and outcomes may be curvilinear. Inclusion of quadratic functions of our resulted in non-significant estimates, and were therefore not included in the models presented in this paper.
} 
mean score on Cognitive Skills, the probability of becoming an early school-leaver is:

$$
\frac{1}{1+e^{-\left(\left(.59^{*}-5.105\right)+1.363\right)}}=.163
$$

For students who are one standard deviation (.19) above or below the mean, the probability of becoming an early school-leaver equals:

$$
\frac{1}{1+e^{-(((.59-.19) *-5.105)+1.363)}}=.343 \text { or } \frac{1}{1+e^{-\left(\left((.59+.19)^{*}-5.105\right)+1.363\right)}}=.068
$$

$<$ Table 3 about here>

In Model 2, we add Achievement Motivation to the model. This model confirms what we had already seen from our descriptive results. We can note that a high score on Achievement Motivation decreases the risk of becoming an early school-lever $(\beta=-.352 * *)$. Another important finding from this model is that the effects for Cognitive Skills hardy change after adding Achievement Motivation to the model. This indicates that the effect of Cognitive Skills on early school-leaving is not caused by differences in Achievement Motivation. Adding controls for (socioeconomic) background hardly affects the estimate for Achievement Motivation, but it does have an impact on the estimate for the Cognitive Skills (Model 3). Including controls for education level at age $12^{7}$ and for parental background clearly reduces the impact of Cognitive Skills.

In Model 4, we include the interaction term between Cognitive Skills and Achievement Motivation. As stated in the hypothesis, we expected a negative interaction effect between Cognitive and Non-Cognitive Skills on early school-leaving. However, the interaction term is not significant.

\subsection{The impact of Personality Traits on early school-leaving}

In the second part of this analysis, we estimate the impact of Personality Traits on early school-leaving. When comparing model 1 with model 5 in table 4, we can conclude that adding Personality Traits to the model does not affect the direct effects of Cognitive Skills. The effect for Cognitive Skills remains virtually identical.

In general we expected to find a negative relationship between Openness to Experience and early school-leaving since Openness to Experience is thought to reflect 'intellectence' and thus to have a positive effect on education outcomes above and beyond intelligence (Ackerman \& Heggestad, 1997).

\footnotetext{
${ }^{7}$ In a separate analysis, we tested if the effects found in this analysis using dummies for educational level atage 12 are comparable to the effects found when performing separate models for each of the three groups. In this approach, our conclusions remained the same. These analyses can be requested from the corresponding author.
} 
People who have higher scores on Openness to Experience tend to be open to new aesthetic, cultural, or intellectual experiences. People with low scores on openness tend to have more conventional, traditional interests. They prefer the plain, straightforward, and obvious over the complex, ambiguous, and subtle. Our model however shows a significant positive effect $\left(\beta=.889^{* * *}\right)$, indicating that high scores on Openness to Experience increase the risk of leaving school early instead of being a protective factor.

The next trait, Conscientiousness, reflects the will to achieve, and the desire for dependability and orderliness. From our literature review, we expected to find a negative effect of conscientiousness on early school-leaving, which is confirmed by the results in our model $\left(\beta=-1.091^{* * *}\right)$.

Extraversion is the third factor, which reflects positive affect and sociability. Based on previous study results we expected to find a positive relationship between early school-leaving and extraversion. However, our results show the opposite. High scores on Extraversion are related to lower probabilities of becoming an early school-leaver $(\beta=-.867 * * *)$. However, this effect becomes non-significant once controls have been added to the model (model 6).

Based on previous findings, we did not expect Agreeableness or likeability to have any direct effect on early school-leaving. From our study, however, we do find a significant negative effect. Thus, being likeable and being able to act in a cooperative manner decreases the probability of leaving school before a minimum level of education is attained. However, this effect becomes non-significant once controls have been added to the model (model 6).

Emotional Stability is the final Personality factor added to model 1 and reflects emotional instability and proneness to psychological distress on the lower bound, and predictability and consistency on the upper bound. In previous studies on the relationship between Personality and educational outcomes, no direct effects of Emotional Stability were found. In our study, we do find a significant positive effect for Emotional Stability $(\beta=.552)$, but this effect becomes very small and non-significant when controls are added to the model (model 6).

<Tabel 4 about here>

We also tested the interaction effects between our five Personality Traits and Cognitive Skills (models 7a to 7e). Contrary to our hypothesis, but in line with the main effect, the interaction effect for Openness to Experience is positive (model 7a). The graphical representation of the interaction effect is depicted in figure 3 .

$<$ Figure 3 about here> 
The graph shows that higher Cognitive Skills decrease the risk of becoming an early school-leaver at all values of Openness to Experience. However, the impact of Cognitive Skills is stronger for students with lower scores on Openness to Experience as is reflected by the steeper angles. Thus, the protective effect of Cognitive Skills is strongest for students who are very conventional and traditional. At the same time, the graph shows that while Openness to Experience is negatively related to early school-leaving for those with low scores on Cognitive Skills (i.e. lower than approximately .25), this effect becomes positive for those with higher scores on Cognitive Skills. For those with high Cognitive Skills, students with high Openness to Experience are more likely to become an early school-leaver, while for those with low Cognitive Skills, high Openness to Experience protects against early school-leaving. This finding is in line with the assumption made by De Fruyt and Mervielde (1996) that high Openness to Experience is actually disadvantageous when reproduction of curricular content is required. It seems to suggest that students with high Cognitive Skills as well as a high Openness to Experience become more frustrated by a setting of reproduction of curricular content. In the case of low Cognitive Skills, this education environment might still be interesting enough for students with a high Openness to Experience.

The interaction between Cognitive Skills and Conscientiousness is negative (model 7b), which is exactly what we expected in our hypotheses. Figure 4 shows the impact of Cognitive Skills on the risk of leaving school early for different values of conscientiousness. For students with low Cognitive Skills, Conscientiousness has a strong protective effect against early school-leaving, while for students with higher than average Cognitive Skills, the difference in the probability of leaving school early is very small and no longer significant. Thus Conscientiousness can compensate for low ability, but within high ability groups, differences in Conscientiousness no longer play an important role.

<Figure 4 about here>

For Agreeableness, we did not expect to find a significant interaction with Cognitive Skills (model 7d). However, our results show that this trait has a negative interaction with Cognitive Skills, indicating that the protective effect of Cognitive Skills is higher for students with high scores on Agreeableness. This effect is depicted in figure 5. We see that students with a low level of Agreeableness show a higher risk of becoming an early school-leaver compared to those who are more agreeable, but this effect is strongest for those with average Cognitive skills. For those with extremely high and extremely low Cognitive Skills, Agreeableness does not seem to affect the risk of becoming an early school-leaver. This might indicate that average skilled students who are agreeable and therefore probably more popular among peers have a lower risk of becoming an early school-leaver. This is confirmed by additional analyses (see Traag, Lubbers and Van der Velden, forthcoming). 
In our hypotheses, we expected to find a negative interaction effect for Extraversion. Although our results (model $7 \mathrm{c}$ ) confirm this $(\beta=-.271)$, the effect is not significant. In model $7 \mathrm{e}$ we estimated the interaction between Emotional Stability and Cognitive Skills, which is negative but not significant.

<Figure 5 about here>

\section{Conclusion and discussion}

Early school-leavers are a very heterogeneous group, comprised of those who cannot attain an upper secondary qualification simply because they lack the cognitive ability, and those who have the ability but nevertheless decide not to invest in further schooling. This paper aimed to investigate how Non-Cognitive Skills can explain individual differences in early school-leaving above and beyond the effect of Cognitive Skills. We wanted to see if differences in Non-Cognitive Skills could explain why adolescents with comparable Cognitive Skills show such different education outcomes. Our analyses provide some insight on how and why some students become early school-leavers, while others do not. Our results showed that Cognitive Skills measured at age 12 do indeed have a strong and direct effect on the risk of becoming an early school-leaver, and that this effect is hardly affected by any of the Non-Cognitive Skills that were added to the model. However, Non-Cognitive Skills also explain part of the individual differences in dropout risk.

First, there is a direct impact of Achievement Motivation. We find that the higher the Achievement Motivation, the lower the risk of leaving school without a full upper secondary qualification. This result is in line with previous studies on the effect of motivation on school success (Alexander, Entwisle, \& Horsey, 1997; Audas \& Willms, 2001; Traag \& Van der Velden, 2011). Achievement Motivation does not affect the impact of Cognitive Skills as was suggested by Vroom's Expectancy Theory (Vroom, 1964): we did not find a significant interaction effect of Achievement Motivation and Cognitive Skills on the risk of becoming an early school-leaver.

Second, we looked at the impact of Personality Traits as a predictor for early school-leaving. We found significant effects for three of the five Personality Traits on the risk of becoming an early schoolleaver. We found a positive effect for Openness to Experience, indicating that it is a risk factor in early school-leaving. This is contrary to what we expected based on the study by Ackerman and Heggestad (1997).When looking at the interaction effect between Cognitive Skills and Openness to Experience, however, we found that the positive effect of the latter is only true for students with high Cognitive Skills. As De Fruyt and Mervielde (1996) suggested this could be because the creative and imaginative nature of these highly skilled students is disadvantageous in settings where reproduction is the main requirement. It 
is very likely that highly skilled students with higher scores on Openness to Experience comply with the education system as long as they have to and leave the system as soon as compulsory education ends. The reverse is true for low skilled students with a high score on Openness to Experience. For these students the education setting may still provide enough intellectual challenges to actually keep them in the system and obtain a full upper secondary qualification.

In general, being conscientious is a protective factor against early school-leaving. High scores on Conscientiousness decrease the probability of becoming an early school-leaver, which is in line with previous studies (Chamorro-Premuzic \& Furnham, 2003; De Fruyt \& Mervielde, 1996; Poropat, 2009). But there is also an interaction effect with Cognitive Skills. The protective effect of Conscientiousness holds specifically for students with low Cognitive Skills. For those with high Cognitive Skills, there is hardly any effect of Conscientiousness. This is in line with findings by Chamorro-Premuzic and Furnham (2003) that higher levels of Conscientiousness can compensate for poor intellectual ability.

For Agreeableness, we found a protective effect on early school-leaving but only for students with average Cognitive Skills. One possible explanation for this protective effects could be that Agreeableness is an important predictor for peer acceptance (Lubbers, Van der Werf, Kuyper, \& Offringa, 2006), while peer acceptance is an important predictor for educational success (Hymel, Comfort, Schonert-Reichel, \& McDougall, 1996; Lubbers, Van der Werf, Snijders, Creemers, \& Kuyper, 2006; Parker \& Asher, 1987; Wentzel, 2003). This is indeed what we find in additional analyses (Traag, Lubbers, \& Van Der Velden, forthcoming).

We did not find any significant effects for Extraversion or Emotional Stability on early schoolleaving, at least after controlling for background characteristics.

In general, we must conclude that Cognitive Skills are indeed an important predictor of early schoolleaving. Some adolescents simply lack the Cognitive Skills to finish a certain level of education. However, Non-Cognitive Skills play an important role in explaining why some students choose to leave the education system in spite of the fact that they have the Cognitive Skills to obtain a full upper secondary qualification. For some, the education system just does not match their Personality, making it hard for them to comply with school rules and regulations and even making it less likely that they will stay in school after compulsory education. An important trait here appears to be Openness to Experience. Students that are very open to experience are viewed as very creative and imaginative, but Openness to Experience can also be a negative factor since it is strongly linked to risk behaviour (Nicholson, Soaneb, Fenton-O'Creevy, \& Willmand, 2005). In their study on the impact of Personality on risk-taking, Nicholson and colleagues make a distinction between stimulation seekers, goal achievers, and risk adapters. Only the first group is truly risk seeking and may be of interest for further studies on early school-leaving because it may very well be precisely the group we previously defined as the 'resigners', a 
group of students that has the ability to achieve in education but who is in search of something else than conforming to conventional careers paths. 
Appendix 1 The Dutch educational system

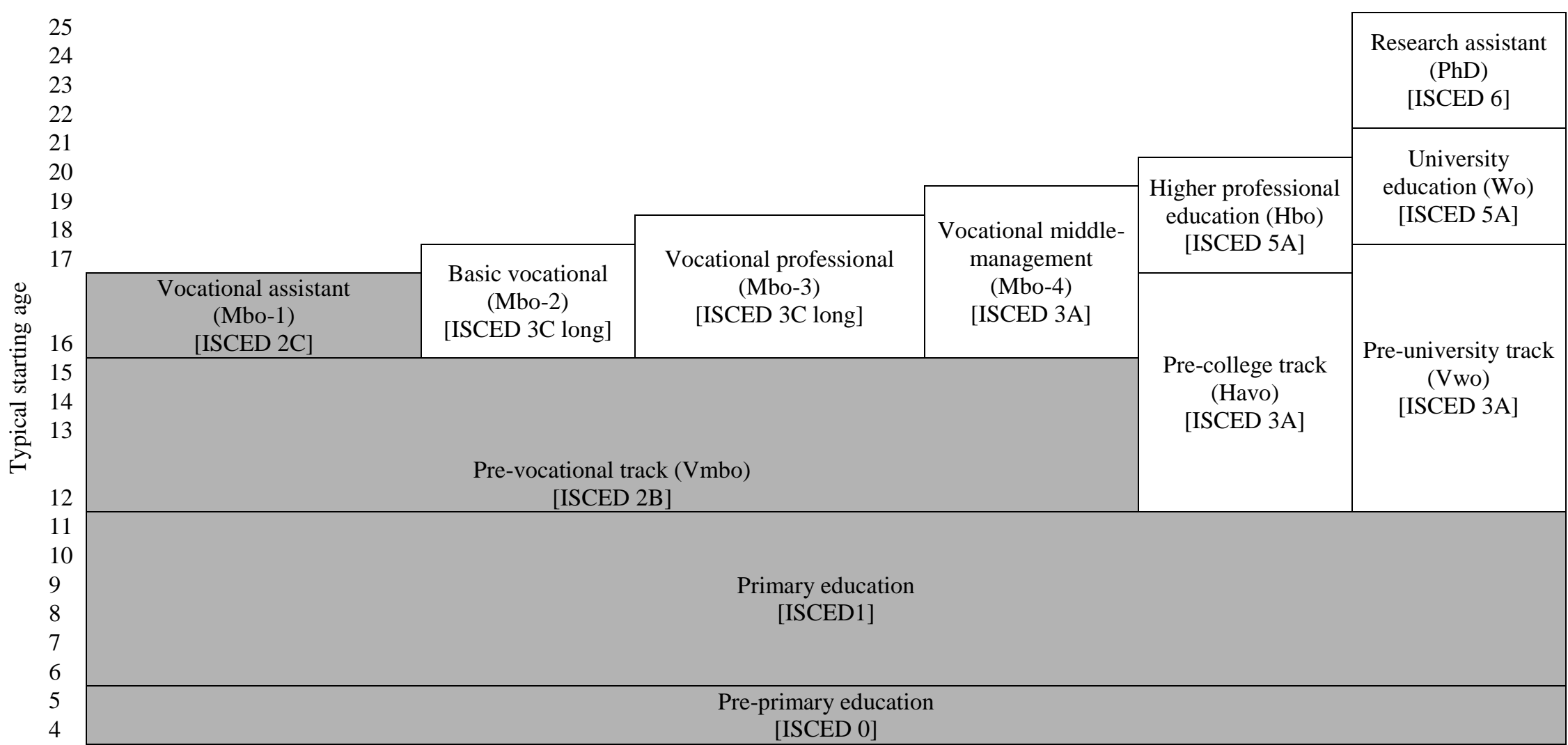

Note: Figure depicts mapping of the current Dutch educational system. ISCED level and programme destination are in [italics]. Dutch

terminology is given in brackets. The national definition of early school-leaving is marked in grey 
Figures and tables

Table 1 Descriptives for early school-leaving by education level in $1^{\text {st }}$ grade of secondary education (row percentages in brackets)

\begin{tabular}{lcccc}
\hline Level first year in secondary education & & Total & Total early & \multicolumn{2}{c}{ Diploma status } \\
\cline { 5 - 6 } & population & $\begin{array}{c}\text { school- } \\
\text { leavers }\end{array}$ & $\begin{array}{c}\text { No diploma } \\
\text { at all }\end{array}$ & $\begin{array}{c}\text { Pre-vocational } \\
\text { education or } \\
\text { vocational assistant }\end{array}$ \\
\hline Total & 14,230 & 2,879 & 362 & 2,444 \\
& & $(20.2 \%)$ & $(2.5 \%)$ & $(17.2 \%)$ \\
\hline Pre-vocational track & 7,591 & 2,450 & 288 & 2,093 \\
Pre-college track & & $(32.3 \%)$ & $(3.8 \%)$ & $(28.5 \%)$ \\
& 3,004 & 251 & 37 & 212 \\
Pre-university track & & $(8.4 \%)$ & $(1.2 \%)$ & $(7.1 \%)$ \\
& 3,635 & 178 & 37 & 139 \\
& & $(4.9 \%)$ & $(1.0 \%)$ & $(3.9 \%)$ \\
\hline
\end{tabular}


Table 2 Mean test scores on Cognitive Skills, Achievement Motivation and Personality Traits by early school-leaving

Total $\begin{gathered}\text { Early school- } \\ \text { leaver }\end{gathered} \quad \begin{gathered}\text { Regular } \\ \text { school-leaver }\end{gathered} \quad$ T-test

Cognitive Skills

Non-Cognitive Skills

Achievement Motivation

Openness to Experience

Conscientiousness

Extraversion

Agreeableness

Emotional stability

N

$* *=\mathrm{p}<.01 *=\mathrm{p}<.05$
.59

.62

.41

.55

.65

.64

.67

14,230

2,879

.62

$47.137 * *$

.45

.61

.63

$4.967 * *$

41

.64

.62

.66

.41

1.370

.55

.66

$4.629 * *$

$7.869 * *$

$.6513 .526 * *$

$.687 .176^{* *}$

11,351 
Table 3 Logistic regression of Cognitive Skills and Achievement motivation on the risk of early schoolleaving

(1)

(2)

(3)

(4)

Term

Constant

$1.363^{* *}$

$1.572 * * *$

$4.514 * * *$

$4.601 * * *$

Cognitive Skills

$\begin{array}{llll}-5.105 * * * & -5.087 * * * & -3.158 * * * & -3.354 * * * \\ & -.352 * * & -.314 * * & -.465\end{array}$

Achievement Motivation

Educational level at age 12

Pre-vocational track (ref.)

Pre-college track

Pre-university track

Sex

Male

Female (ref).

Migrant status

Migrant

Native Dutch (ref).

Parental education

Parental income

Parental communication

Controls for missing values

No

$-.826 * * * \quad-.827 * * *$

$-1.051 * * * \quad-1.052 * * *$

$.462 * * * \quad .462 * * *$

$\begin{array}{ll}-.009 & -.008\end{array}$

$-.081 * * * \quad-.081 * * *$

$-.265 * * * \quad-.265 * * *$

$-.511 * * * \quad-.511 * * *$

Yes Yes

Cognitive Skills * Achievement Motivation

.322

Log Likelihood

$-6183.0672-6180.0057$

$-5836.1345$

$-5836.059$

Notes: Sample size is 14,230 observations. ${ }^{* * *}=\mathrm{p}<.01 . * *=p<.05 . *=p<.1$ 
Table 4 Logistic regression of Cognitive Skills and Personality Traits on the risk of early school-leaving

\begin{tabular}{|c|c|c|c|c|c|c|c|c|}
\hline & $(1)$ & $(5)$ & $(6)$ & $(7 a)$ & $(7 b)$ & $(7 \mathrm{c})$ & $(7 d)$ & $(7 e)$ \\
\hline \multicolumn{9}{|l|}{ Term } \\
\hline Constant & $1.363 * * *$ & $2.450 * * *$ & $5.062 * * *$ & $5.622 * * *$ & $4.127 * * *$ & $4.980 * * *$ & $4.335 * *$ & $4.715^{* * *}$ \\
\hline Cognitive Skills & $-5.105 * * *$ & $-5.139 * * *$ & $-3.275 * * *$ & $-4.376 * * *$ & $-1.330 *$ & $-3.105 * * *$ & $-1.681 * * *$ & $-2.530 * * *$ \\
\hline Openness to Experience & & $.889 * * *$ & $.758 * * *$ & -.613 & $.733 * * *$ & $.760 * * *$ & $.753 * * *$ & $.756 * * *$ \\
\hline Conscientiousness & & $-1.091 * * *$ & $-1.352 * * *$ & $-1.347 * * *$ & .403 & $-1.353 * * *$ & $-1.365 * * *$ & $-1.360 * * *$ \\
\hline Extraversion & & $-.867 * * *$ & -.269 & -.285 & -.278 & -.138 & -.283 & -.272 \\
\hline Agreeableness & & $-1.016 * * *$ & -.101 & -.084 & -.108 & -.103 & $1.125^{*}$ & -.105 \\
\hline Emotional stability & & $.552 * *$ & .145 & .137 & .090 & .146 & .138 & .689 \\
\hline \multicolumn{9}{|l|}{ Education level at age 12} \\
\hline \multicolumn{9}{|l|}{ Pre-vocational track (ref.) } \\
\hline Pre-college track & & & $-.835 * * *$ & $-.843 * * *$ & $-.839 * * *$ & $-.834 * * *$ & $-.828 * * *$ & $-.833 * * *$ \\
\hline Pre-university track & & & $-1.069 * * *$ & $-1.093 * * *$ & $-1.088 * * *$ & $-1.067 * * *$ & $-1.055 * * *$ & $-1.064 * * *$ \\
\hline \multicolumn{9}{|l|}{ Sex } \\
\hline Male & & & $.454 * * *$ & $.455 * * *$ & $.457 * * *$ & $.454 * * *$ & $.452 * * *$ & $.424 * * *$ \\
\hline \multicolumn{9}{|l|}{ Female (ref). } \\
\hline \multicolumn{9}{|l|}{ Migrant status } \\
\hline Migrant & & & .010 & .010 & .010 & .010 & .012 & .010 \\
\hline Native Dutch (ref). & & & & & & & & \\
\hline Parental education & & & $-.083 * * *$ & $-.083 * * *$ & $-.084 * * *$ & $-.083 * * *$ & $-.084 * * *$ & $-.084 * * *$ \\
\hline Parental income & & & $-.275 * * *$ & $-.276 * * *$ & $-.272 * * *$ & $-.275 * * *$ & $-.275 * * *$ & $-.275 * * *$ \\
\hline Parental communication & & & $-.459 * * *$ & $-.465 * * *$ & $-.455 * * *$ & $-.459 * * *$ & $-.458 * * *$ & $-.461 * * *$ \\
\hline Controls for missing values & No & No & Yes & Yes & Yes & Yes & Yes & Yes \\
\hline Cognitive Skills * Openness to Experience & & & & $2.744 * * *$ & & & & \\
\hline Cognitive Skills $*$ Conscientiousness & & & & & $-3.571 * * *$ & & & \\
\hline Cognitive Skills $*$ Extraversion & & & & & & -.271 & & \\
\hline Cognitive Skills * Agreeableness & & & & & & & $-2.585 * *$ & \\
\hline Cognitive Skills * Emotional Stability & & & & & & & & -1.128 \\
\hline Log Likelihood & -6183.0672 & -6123.2497 & -5794.8454 & -5792.0758 & & & & \\
\hline
\end{tabular}


Figure 1 Distribution of Cognitive Skills and Achievement Motivation by early school-leaving
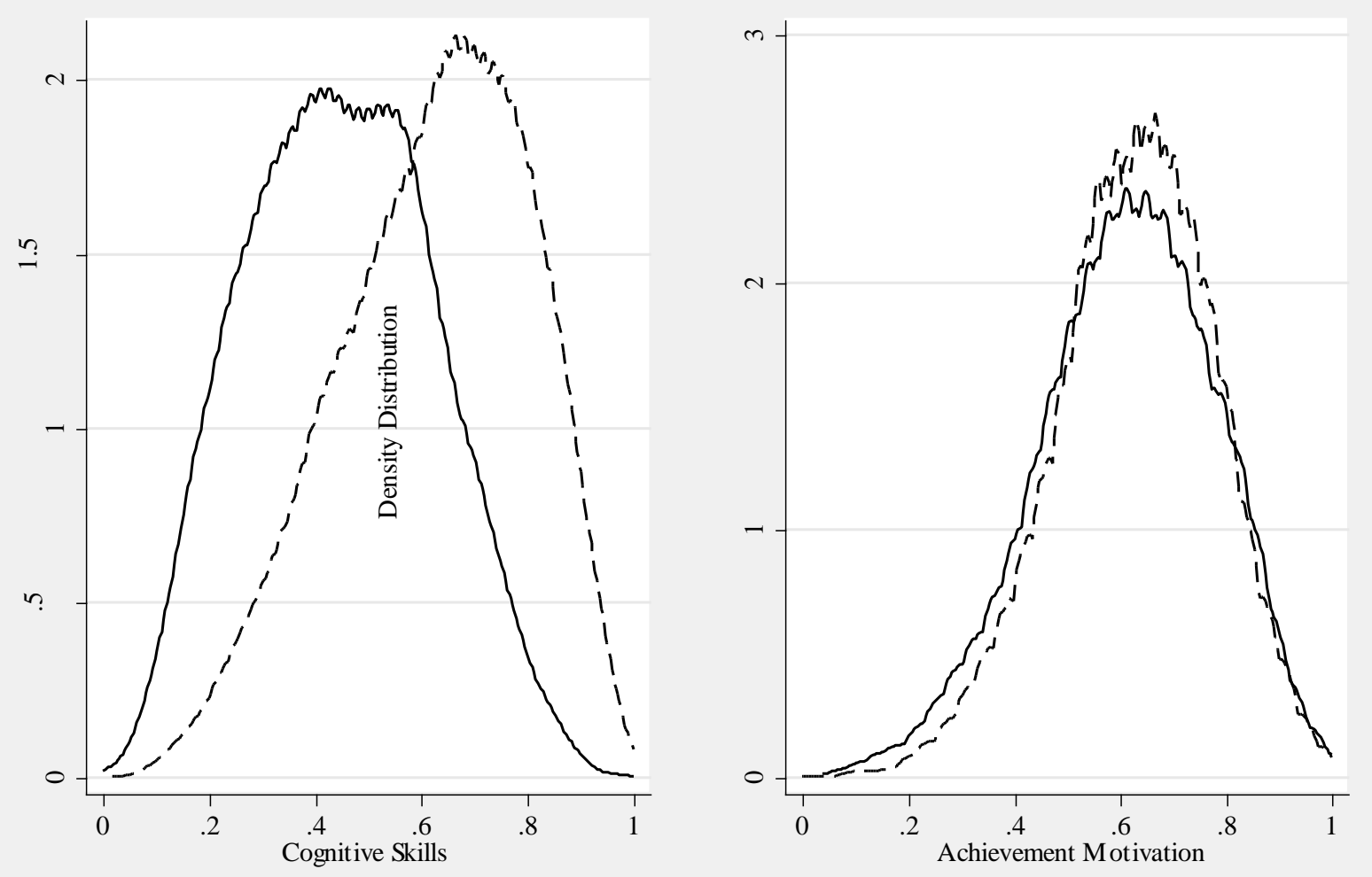

Early school-leaver $\quad-----$ Attained at least basic vocational education 
Figure 2 Distribution of scores on Personality Traits by early school-leaving
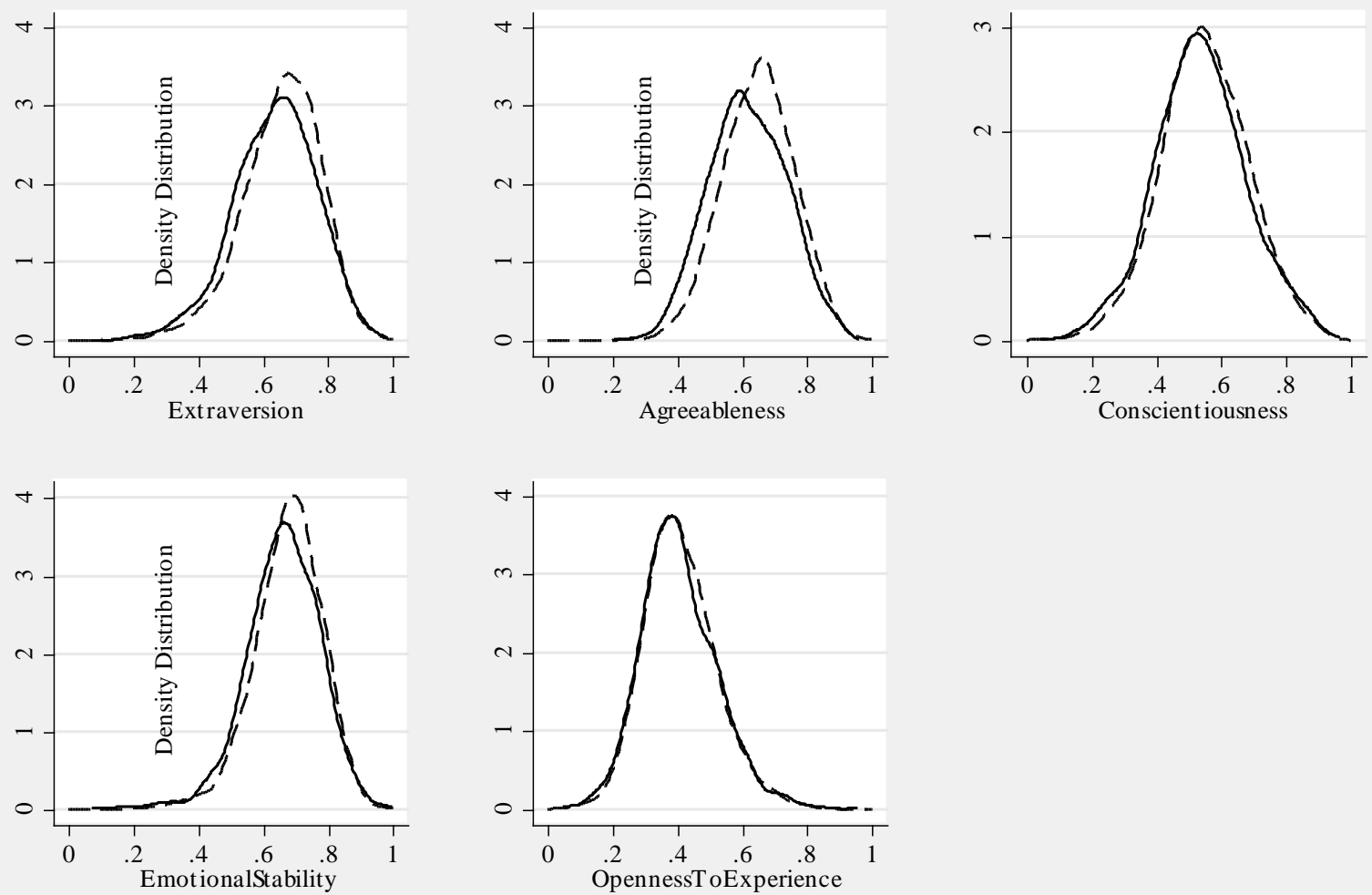
Figure 3 Probability of early school-leaving by Cognitive Skills and Openness to Experience

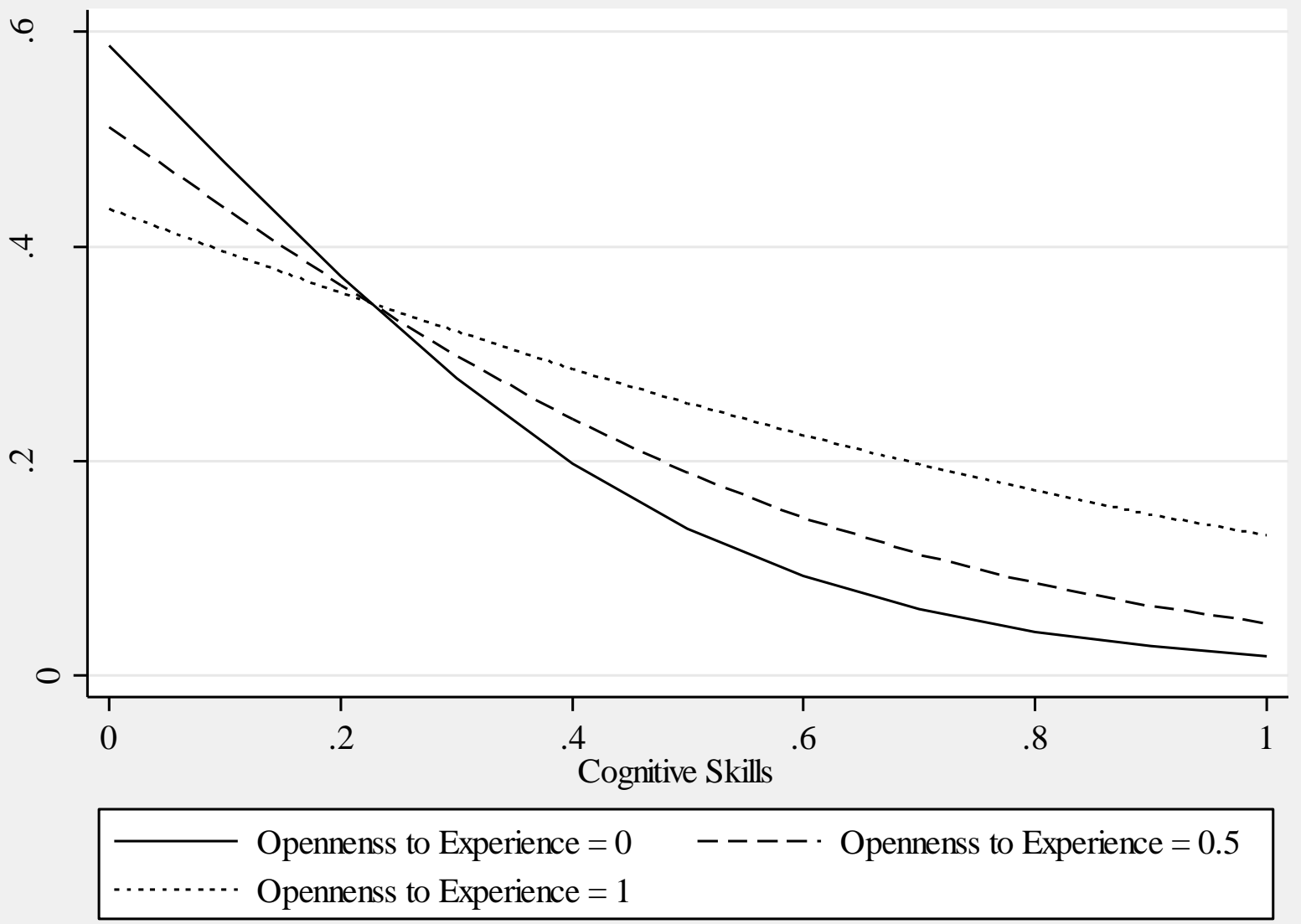

Note: All other variables in the model are kept at their means. 
Figure 4 Probability of early school-leaving by Cognitive Skills and Conscientiousness

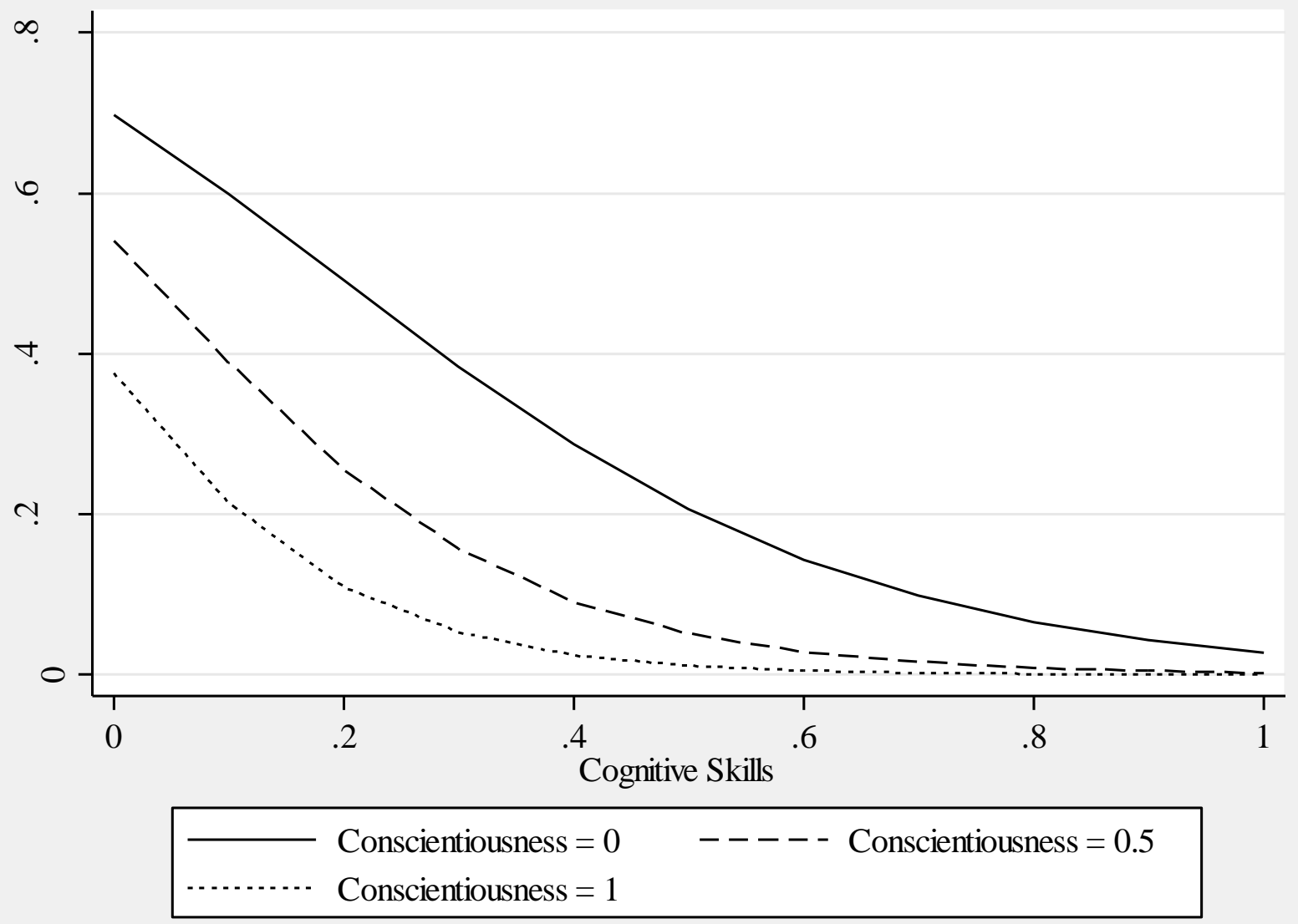

Note: All other variables in the model are kept at their means. 
Figure 5 Probability of early school-leaving by Cognitive Skills and Agreeableness

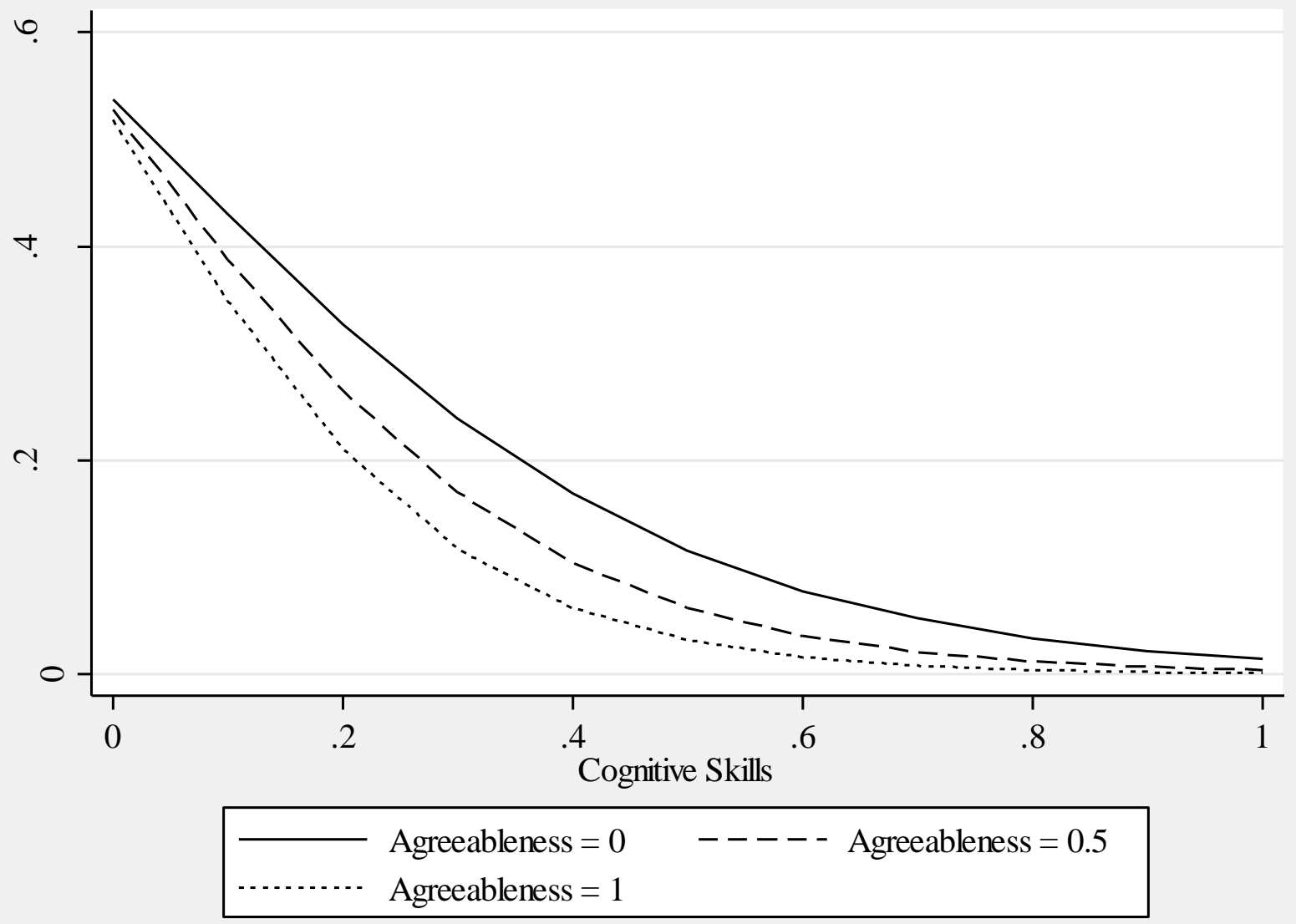

Note: All other variables in the model are kept at their means. 
Ackerman, P. L., \& Heggestad, E. D. (1997). Intelligence, Personality, and Interests: Evidence for Overlapping Traits. Psychological Bulletin, 121(2), 219-245.

Alexander, K., Entwisle, D., \& Horsey, C. S. (1997). From first grade forward: early foundations of high school dropout. Sociology of Education, 70, 87-107.

Alexander, K., Entwisle, D., \& Kabbani, N. (2001). The dropout process in life course perspective: early risk factors at home and school. Teachers College Record (103), 760-822.

Allen, J., \& Meng, C. (2010). Voortijdig schoolverlaters: aanleiding en gevolgen. Maastricht: Researchcentrum voor Onderwijs en Arbeidsmarkt (ROA).

Audas, R., \& Willms, J. D. (2001). Engagement and dropping out of school: A life course perspective. Unpublished Working Paper for the Applied Research Branch, Strategic Policy, Human Resources Development.

Bhrolcháin, M. N., Chappell, R., Diamond, I., \& Jameson, C. (2000). Parental divorce and outcomes for children: Evidence and inter-pretation. European Sociological Review, 16(1), 67-91.

Binet, A., Simon, T., \& Kite, E. S. (1916). The development of intelligence in children (The Binet-Simon Scale). . Baltimore, MD: Williams \& Wilkins Co. .

Borghans, L., Duckworth, A. L., Heckman, J. J., \& Weel, B. t. (2008). The economics and psychology of personality traits. Maastricht: Research Centre for Education and the Labour Market.

Bosker, R. J., Van Der Velden, R. K. W., \& Hofman, W. H. A. (1985). Een generatie geselecteerd. Deel I: De loopbanen. Groningen: RION.

Cairns, R. B., Cairns, B. D., \& Neckerman, H. J. (1989). Early school dropout: configurations and determinants. Child Development, 60, 1437-1452.

Chamorro-Premuzic, T., \& Furnham, A. (2003). Personality predicts academic performance: Evidence from two longitudinal university samples. Journal of Reserach in Personality, 37, 319-338.

---. (2005). Personality and intellectual competence. New Jersey: Lawrence Erlbaum Associates.

---. (2006). Intellectual Competence and the Intelligent Personality: A Third Way in Differential Psychology. Review of General Psychology, 10(3), 251-267.

De Fruyt, F., \& Mervielde, I. (1996). Personality and interests as predictors of educational streaming and achievement. European journal of personality, 10(5), 405-420.

De Graaf, P. M. (1986). The impact of financial and cultural resources on educational attainment in the Netherlands. Sociology of Education, 59(237-246).

Ensminger, M. E., \& Slusarcick, A. L. (1992). Paths to high school graduation and dropout: a longitudinal study of a first-grade cohort. Sociology of Education, 65, 95-113.

Fruyt, F. d., \& Mervielde, I. (1996). Personality and interests as predictors of educational streaming and achievement. European journal of personality, 10(5), 405-420.

Furnham, A. (2008). Personality and intelligence at work: exploring and explaining individual differences at work. New York: Routledge.

Heard, H. E. (2004). The life course of family structure and adolescent school achievement: Racial and ethnic differences. Unpublished Paper presented at the Population Association of America 2004 meeting, Boston. .

Heckman, J. J., \& Rubinstein, Y. (2001). The Importance of Noncognitive Skills: Lessons from the GED Testing Program. The American Economic Review, 91(2), 145-149.

Heckman, J. J., Stixrud, J., \& Urzua, S. (2006). The effects of cognitive and noncognitive abilities on labor market outcomes and social behaviour. Journal of Labor Economics 24(3), 411-482.

Hendriks, A. A. J., Kuyper, H., Offringa, G. J., \& Van der Werf, M. P. C. (2008). Assessing Young Adolescents' Personality With the Five-Factor Personality Inventory. Assessment, 15(3), 304-316.

Hendriks, A. A. J., Perugini, M., Angleitner, A., Ostendorf, F., Johnson, J. A., Fruyt, F. d., et al. (2003). The five factor personality inventory: Cross-cultural generalizability across 13 countries. European journal of personality, 17, 347-373. 
Hermans, H. J. M. (1970). A questionnaire measure of achievement motivation. The Journal of Applied Psychology, 54, 353-363.

Hustinx, P. W. J., Kuyper, H., M.P.C. Van der Werf, M. P. C., \& Dijkstra, P. (2009). Achievement motivation revisited: New longitudinal data to demonstrate its predictive power. Educational Psychology, 29, 561-582.

Hymel, S., Comfort, C., Schonert-Reichel, K., \& McDougall, P. (1996). Academic failure and school dropout: The influence of peers. In J. Juvonen \& K. R. Wentzel (Eds.), Social motivation: Understanding children's school adjustment. Cambridge: Cambridge University Press.

Judge, T. A., Higgins, C. A., Thoresen, C. J., \& Barrick, M. R. (1999). The big five personality traits, general mental ability , and career success across the life span. Personnel Psychology, 52(3), 621652.

Kuyper, H., Dijkstra, P., Buunk, A. P., \& Werf, M. P. C. v. d. (2011). Social comparisons in the classroom: An investigation of the better than average effect among secondary school children. Journal of School Psychology, 49, 25-53.

Kuyper, H., Lubbers, M. J., \& Van der Werf, M. P. C. (2003). VOCL'99-1: Technisch rapport. Groningen: GION.

Kuyper, H., \& Van der Werf, M. P. C. (2003). VOCL'99: De resultaten in het eerste leerjaar. Groningen: GION.

Kuyper, H., Werf, M. P. C. v. d., \& Lubbers, M. J. (2000). Motivation, meta-cognition and self-regulation predictors of long term educational attainment. Educational Research and Evaluation, 6(181205).

Lamb, S. (1994). Dropping out of school in Australia: Recent trends in participation and outcomes. Youth and Society, 26(2), 194-222.

Lubbers, M. (2004). The social fabric of the classroom. Peer relations in secondary education. . Groningen: GION.

Lubbers, M. J., Van der Werf, M. P. C., Kuyper, H., \& Offringa, J. (2006). Predicting Peer Acceptance in Dutch Youth: A Multilevel Analysis. Journal of Early Adolescence, 26(1), 4-35.

Lubbers, M. J., Van der Werf, M. P. C., Snijders, T. A. B., Creemers, B. P. M., \& Kuyper, H. (2006). The impact of peer relations on academic progress in junior high. Journal of School Psychology, 44, 491-512.

Matthews, G., Zeidner, M., \& Roberts, R. D. (2006). Models of Personality and Affect for education: A Review and Synthesis. In P. A. Alexander \& P. H. Winne (Eds.), Handbook of educational psychology (pp. 173). Mahwah, NJ: Lawrence Erlbaum.

McCrae, R. R., \& Paul T. Costa, J. (1997). Personality Trait Structure as a Human Universal. American Psychologist, 52, 509-516.

McKenzie, J., \& Tindell, G. (1993). Anxiety and academic achievement: Further Furneaux factor findings Personality and Individual Differences, 15(6), 609-617

McLanahan, S., \& Sandefur, G. (1994). Growing up with a single parent. What hurts, what helps? . Cambridge: Harvard University Press.

Nicholson, N., Soaneb, E., Fenton-O'Creevy, M., \& Willmand, P. (2005). Personality and domain-specific risk taking. Journal of Risk Research $8(2)$.

Nord, C. W., \& West, J. (2001). Fathers' and others' involvement in their children's schools by family type and resident status. Washington, DC: U.S. Department of Education. National Center for Education Statistics.

O'Connor, M. C., \& Paunonen, S. V. (2007). Big Five personality predictors of post-secondary academic performance. Personality and Individual Differences, 43, 971-990.

Parker, J. G., \& Asher, S. R. (1987). Peer relations and later personal adjustment: Are low-accepted children at risk? . Psychological Bulletin, 102(3), 357-389. 
Petrides, K. V., Chamorro-Premuzic, T., Frederickson, N., \& Furnham, A. (2005). Explaining individual differences in scholastic behaviour and achievement. British Journal of Educational Psychology, 75, 239-255.

Poropat, A. E. (2009). A meta-analysis of the five-factor model of personality and academic performance. Psychological Bulletin, 135(2), 322-338.

Researchcentrum voor Onderwijs en Arbeidsmarkt. (2011). Schoolverlaters tussen onderwijs en arbeidsmarkt 2010. Maastricht: Schoolverlaters tussen onderwijs en arbeidsmarkt 2010.

Rothstein, M. G., Paunonen, S. V., Rush, J. C., \& King, G. A. (1994). Personality and cognitive ability predictors of performance in graduate business school. Journal of Educational Psychology, 86(516-530).

Rumberger, R. W. (1983). Dropping out of high school: The influence of race, sex and family background. American Educational Reaearch Journal, 20(2), 199-220.

---. (1987). High school drop-outs: A review of issues and evidence. Review of Educational Research, 87(2), 101-121.

Steinmayr, R., \& Spinath, B. (2008). Sex differences in school achievenment: What are the roles of personality and achievement motivation? . European journal of personality, 22, 185-209.

Traag, T., Lubbers, M. J., \& Van Der Velden, R. K. W. (forthcoming). That's what friends are for? The impact of peer characteristics on early school-leaving.

Traag, T., \& Van der Velden, R. (2011). Early school-leaving in the Netherlands: The role of family resources, school composition and background characteristics in early school-leaving in lower secondary education. Irish Education Studies, 30(1).

Van Berkel, K. (1999). Steekproef voor schoolloopbaan onderzoek VOCL'99. Heerlen: Statistics Netherlands.

Van Heesch, M. M. J., Bosma, H., Traag, T., \& Otten, F. (2011). Hospital admissions and school dropout: a retrospective cohort study of the 'selection hypothesis'. European Journal of Public Health.

Vroom, V. H. (1964). Work and Motivation. New York: Wiley.

Wentzel, K. R. (2003). Sociometric Status and Adjustment in Middle School: A Longitudinal Study. Journal of Early Adolescence, 23, 5-28. 